(10) Lubosch, W._- "Ueber die Geschlectsdifferenzirung bei Ammocœes." Verh. Anat. Ges. xvii., 1903.

(11) Felix, W.- 'Handbuch der Vergleichenden Entwi'ckelungslehre der Wirbelthiere,' edited by O. Hertwig, Bd. iii., 1906.

(12) Stephan, Pierre.— "De l'hermaphroditisme chez les Vertébrés." Annales de la Faculté des Sciences de Marseille, t. xii., 1901.

P.S. - Since the reading of this paper Dr. Calman has kindly drawn my attention to a paper by Zograf (Zool. Anz. xxx., 1907), in which the author records the occurrence of ova in the testes of Apus.

February 4, 1908.

H.G. The Duke of Bedford, K.G., President, in the Chair.

Mr. F. Martin Duncan gave a lantern exhibition of the results he had obtained with the Autochrome Natural Colour Process of the brothers Lumière as applied to zoological subjects.

The following papers were read :-

1. The Duke of Bedford's Zoological Exploration in Eastern Asia.-VII. List of Mammals from the Tsu-shima Islands. By Oldfield Thomas, F.R.S., F.Z.S.

[Received December 31, 1907.]

In continuation of his collecting-work in Eastern Asia, Mr. Malcolm Anderson visited the Tsu-shima Islands, between Japan and Korea, at the beginning of this year, and made the collection enumerated below.

The fauna would seem to be comparatively poor, so far as the number of species is concerned, but it is of much interest, owing to the curious mixture of forms which it contains, some of its members being absolutely Japanese in relationship, and others Korean - a mixture the cause of which it is at first sight difficult to guess.

Putting aside the species which, for one reason or another, are 
indefinite in relationship, we have the following characteristically Japanese forms :-

Urotrichus talpoides adversus. No Urotrichus recorded from Korea. Martes melampus tsuensis. No Marten of this type known from Korea.

Apodemus speciosus speciosus. Replaced in Korea by the very different $A$. s. peninsulce.

, geisha sagax.

(No A. agrarius.

A. geisha common in Japan, absent from Korea.

Dominant in Korea, absent from Japan.)

On the other hand, the Korean forms are :-

Crocidura corece.

Felis microtis.

Lutreola sibirica.
Replaced in Japan by $C$.dsi-nezumi. No Cat of any sort known in Japan. Replaced in Japan by $L$. itatsi.

The balance even in mere numbers is thus on the side of the Japanese relationship of Tsu-shima. But further it is to be noted that three out of the four animals with Japanese affinities belong to special local subspecies, indicating that they are certainly indigenous, having been in the islands long enough to get more or less modified. On the other hand, all the Korean forms are identical with their mainland relatives and have perhaps been accidentally introduced through human agency.

Mr. Anderson's notes on the physical features of the islands are as follows :--

\section{"Notes on Tsu-shima.}

"Tsu-shima (literally Opposite Island) consists in reality of two main islands, the southern being called Shimono, the northern Kamino-shima. The two are separated by a narrow channel only, which, I am told, is sometimes dry at low tide. Both islands are hilly throughout, the highest point being $2100 \mathrm{ft}$. The hills are steep and their soil very thin, so, as the valleys are exceedingly narrow, arable land is scarce indeed, and the population almost entirely restricted to the fishing-villages on the coasts. The hills are wooded, especially in Kamino-shima, where pines, oaks, Cryptomeria, Chamæcyparis, and Camelia are the principal trees. Precipitation is abundant, but, owing to the shortness of the streams and the stony nature of the soil, which is composed of fragments of shale, the brooks are usually dry, especially at their lower ends ; it is only during, or just after, a heavy rainfall that their water reaches the sea.

"Tsu-shima is surrounded by a few islets of no importance. The nearest land is Iki, 32 miles to the south-east, but the Korean mainland is not more than four or five miles farther, while some considerable islands of the Korean Archipelago are less than forty miles from Kamino. Between Shimono-shima and 
Iki the sea reaches no greater depth than 65 fathoms (Japanese Admiralty chart), while between Kamino-shima and Korea it falls, in one restricted area near the coast of Kamino, to a depth of 105 to 118 fathoms.

"I collected in Tsu-shima from Jan. 1st to Feb. 3rd, 1907.

"No Hares or Squirrels are known to the people of Tsu-shima, and I could find no traces of Evotomys or Microtus, or indeed of any other wild species."-M. P.A.

In addition to the specimens collected by Mr. Anderson I have inserted references to a few mammals obtained by Mr. P. A. Holst in 1891 when travelling on behalf of the late Mr. Henry Seebohm, by whom they were presented to the British Museum. Among these are the original examples of the Tsu-shima Marten, described by me in 1897. Two further new subspecies are now described.

After Tsu-shima Mr. Anderson visited the Iki and Goto Islands, the resulting collections proving that those groups are absolutely similar to S.W. Japan in their mammal fauna.

Mr. Anderson's series amounts to 151 skins, with their skulls, and is presented as before to the National Museum by His Grace the Duke of Bedford, K.G.

\section{Rhinolophus connutus Temm.}

\section{(92.3.20.1-2. P. A. Holst. 1891.)}

This is the only Bat as yet recorded from Tsu-shima.

\section{Mogera wogura kanai Thos.}

(92.9.2.2. P. A. Holst. 1891.)

Unfortunately $\mathrm{Mr}$. Anderson was not able to obtain further specimens of the Tsu-shima Mole, which I have provisionally assigned*, on the single example above recorded, to the smaller south-western form $M$. wogura.

"Not secured or even seen, but natives tell of a black Mole, and also of a much larger buff-coloured one, which they say they see in spring and summer."-M. P.A.

3. Urotrichus talpoides adversus $\uparrow$, subsp. $\mathrm{n}$.

ㅊ. 1243, 1244, 1272, 1274, 1275 . 우. 1263, 1273, 1279. Sasuna, N. Island. 100'.

‥ 1199, 1204, 1213, 1215, 1221, 1234. ㅇ. 1214. Izuhara, S. Island. $300^{\prime}$.

General colour very brown, furthest from the slaty black of the Hondo subspecies. Size less than in the Kiushiu form, the head and body measurement rarely attaining $90 \mathrm{~mm}$. Tail comparatively long, averaging nearly $34 \mathrm{~mm}$., its hairs also particularly long. Fur thick and soft-hairs of back about $6.5 \mathrm{~mm}$. in length,

* Suprà, p. 463.

Proc. Zool. Soc.-1908, No. IV.

$\dagger$ Tsu-shima $=$ Opposite Island. 
and therefore nearly a millimetre longer than those of the more northern $U$. $t$. hondonis, measured equally on winter specimens.

Dimensions of the type :-

Head and body $89 \mathrm{~mm}$.; tail 34 ; hind foot 15 .

Skull-greatest length $26.5 \mathrm{~mm}$.; basal length 22.3 ; greatest breadth 13 .

$H a b$. Tsu-shima Islands-type from Sasuna, N. Island.

Type. Adult male. B.M. No. 8.2.26.1. Original number 1243. Collected 16th January, 1907.

"Fairly common in damp wooded ravines in Tsu-shima, where it was often trapped beneath or beside large stones. Insects are often among the stomach contents, and here no vegetable matter* was recognised in their stomachs, but one example was caught in a trap baited with barley."-M. P.A.

A renewed examination of the fine series of Urotrichus obtained by Mr. Anderson in the Japanese Archipelago shows that each of the three main islands has a form which may be subspecifically separated from the others, and that Tsu-shima has a fourth. Their characters are shown in the following synopsis :-

A. Tail comparatively long, averaging about $33 \mathrm{~mm}$.

a. Size larger, head and body 90-101 mm. Colour

dark brown. Kiu-shiu.........................
b. Size smaller, head and body $84-91 \mathrm{~mm}$. Colour paler brown. Tsu-shima.

U. t. talpoides Temm.

U. t. adversus (suprà).

B. Tail comparatively short.

c. Tail averaging just over $30 \mathrm{~mm}$. (range 28-34). Colour brown. Shi-koku

d. Tail averaging $27 \mathrm{~mm}$. (range 23-30). Colour slaty-grey. Hondo

U. t. centralis (infrà).

U. t. hondonis (infrà).

The series on which these averages are based are from 15 to 22 in number, and are therefore large enough to eliminate any material error due to individual variation.

Details of the Shi-koku and Hondo subspecies :-

URotrichus talpoides CENTRALIS $\uparrow$, subsp. n.

Size averaging rather less than in true talpoides, larger than in adversus (head and body 90-97 mm., the majority of specimens 92-95). Tail decidedly shorter than in either talpoides or adversus (average of 22 specimens $30 \cdot 75$ mm., extremes 28-34). Fur about $6 \mathrm{~mm}$. in length on the back (winter). General colour deep brown, darker than adversus, lighter than talpoides.

Dimensions of the type :-

Head and body $94 \mathrm{~mm}$. ; tail 32 ; hind foot 16 ; upper toothrow $11 \cdot 2$.

Hab. Island of Shi-koku. Type from Jinrio, Tokushima Ken. Alt. 500'.

Type. Adult female. B.M. No. 6.1.4.68. Original number 289. Collected 14th February, 1905.

* Cf. P. Z. S. 1905, ii. p. 341.

$\uparrow$ Central as compared to other forms, both in size, colour, length of tail, and locality. 
Urotrichus talpoides hoNdonis, subsp. $\mathrm{n}$.

Urotrichus talpoides pilirostris Thos. P.Z.S. 1905, ii. p. 342 (1906), nec Dymecodon pilirostris True, P. U.S. Nat. Mus. 1886, p. 97 .

Size medium, head and body length generally about $90 \mathrm{~mm}$. Tail shortest in the genus, the average of 17 specimens being $27 \mathrm{~mm}$., with a range of from 23 to 30 . Fur about $5 \cdot 5$ to $6 \mathrm{~mm}$. in length on the back. General colour "slate-black" (grey No. 2), with a slight tirige of "mouse-grey," the brown tone found in the more western forms absent.

Dimensions of the type :-

Head and body $91 \mathrm{~mm}$. ; tail 26 ; hind foot 14 ; upper toothrow $10 \cdot 1$.

Hab. Hondo. Type from Nakaomi, near Ohito, Izu.

Type. Male. B.M. No. 6.1.4.97. Original number 144. Collected 13th December, 1904.

This form needs a name different from that I applied to it in 1905 , for the reasons explained in the footnote*.

4. Crocidura coree Thos.

․ 1242-1247. Sasuna, N. Island.

o. 1203. Izuhara, S. Island.

This is one of the three Tsu-shima species of Korean rather than Japanese affinity, but must not be considered as of great importance from a geographical standpoint, as Shrews of this genus are undoubtedly often carried about on shipboard from place to place, so that this Shrew may have been accidentally introduced from Korea.

"Rare. None seen but the three preserved."-M. P. A.

* Since I wrote the paper on Japanese Mammals above referred to, the Museum has received from Mr. K. Kanai, a Japanese who had been taught collecting by $\mathrm{Mr}$. Anderson, a small series of specimens from Central Southern Hondo. Among these there are four examples of an Insectivore entirely new to us, allied to Urotrichus, but smaller and differing in various details, and it seemed probable, therefore, that these represented Mr. True's Dymecodon pilirostris, which had been supposed to have been based on a young Urotrichus.

By Mr. True's kindness and the great courtesy of the authorities of the United States National Museum I have been permitted the loan of the type specimen of D. pilirostris, and a comparison shows at once that the above suggestion is correct, and that Mr. Kanai's specimens represent the adult and Mr. True's type the young of a species generically quite distinct from Urotrichus. I am therefore now able to confirm the absolute correctness of Mr. True's distinction of Dymecodon, on which I had previously thrown doubt.

The adult dentition of Dymecodon does not differ in number from that of the young described by Mr. True, and appears to be, so far as I am able to understand the homologies of the teeth,

$$
\begin{aligned}
& 1.2 .3 \quad 1 \quad 1.0 .3 .4 \\
& \text { I. } \frac{1.2 .3}{0.2 .3} ; \text { C. } \frac{1}{1} ; \text { P. } \frac{3.4}{3.4} ; \text { M. } \frac{1.2 .3}{1.2 .3} \text {. }
\end{aligned}
$$

the permanent $\mathrm{p}^{1}$ being present with the milk-teeth, and being included in the number recorded by Mr. True. The formula of Urotrichus is the same, except that the lower canine is absent, the statement made by some authors that there are four 
5. Felis microtis M.-Edw.

ㅇ․ 1198, 1278. Sasuna, N. Island. $300^{\prime}$.

(91.10.14.1, 92.1.11.3, and 96.2.28.1. P. A. Holst. 1891.)

This is an essentially Korean member of the Tsu-shima fauna, no, member of the genus Felis being found in Japan.

"The Wild Cat is common in Tsu-shima, living near the seashore, where it is said to go nightly at low tide to fish. In the stomach of $1278 \mathrm{I}$ found fish-bones and some feathers of the pheasant. The natives consider the flesh of the Cat especially delicate food. Native name: 'Yama-niku'=Mountain-Cat." M. P.A.

\section{Martes melampus tsuensis Thos.}

\section{1261-1277. Sasuna, Tsu-shima.}

(91.10.14.2-3, 92.1.11.1-2. P. A. Holst. 1891.)

When describing this form in $1897^{*}$ I had not any Japanese Martens of the bedfordi type to compare it with, that being clearly the animal to which it is most allied, and not the typical melampus. Now, however, a comparison of Mr. Anderson's skins of the two shows that, in winter pelage, the Tsu-shima Marten is distinguishable from that of Southern Hondo by its whitish crown and the absence of the yellowish tuft at the end of the tail.

"Common in Northern Tsu-shima, and occurring in the South Island. Like the Cat it is most often found near the sea. The stomachs of the two caught were empty, but the animals were excessively fat. They are considered a fine food by the peasantry of the islands, who call them 'Wata-boshi' = Cotton-cap."M. P.A.

premolars and only $\frac{2}{1}$ incisors being evidently wrong, as a comparison of the milk and permanent teeth both of Dymecodon and Urotrichus shows that the antepenultimate premolar does not change, and is therefore $\mathrm{p}^{1}$, while distinct traces of the premaxillo-maxillary suture can be seen just behind the third tooth in the upper jaw. Of the incisors it is probably $i_{1}$ that is missing in the lower jaw.

In the form and relative proportions of the permanent teeth Dymecodon resembles Urotrichus very closely, the curious alternation in size of the lower teeth, on which Mr. True based the name of the genus, not existing in the later dentition, and it is in fact only due to the milk $\mathrm{p}_{2}$ being, not unnaturally, smaller than the permanent $\mathrm{p}_{1}$ which coexists with it.

But iu the milk stages, which have not previously been compared, the differences are far greater. For while in Dymecodon the two anterior incisors are subequal, similar in form, scarcely overtop the teeth posterior to them, and in Mr. True's words "resemble the teeth of Phocana," those of Urotrichus have already progressed a long way towards the specialisation found in the adults of both genera, $\mathrm{mi}^{1}$ considerably surpassing $\mathrm{mi}^{2}$, and this again being much longer than $\mathrm{mi}^{3}$; and below again the most anterior tooth ( $\mathrm{mi}_{2}$, as I suppose) is decidedly longer than any of the next three teeth.

From this it would appear that Dymecodon is in a more primitive stage of evolution than Urotrichus.

Mr. Kanai's specimens of Dymecodon were captured at Shibu, on Mt. Yatsugatake, Nagano Ken, N.W. of Yokohama, at an altitude of $5700^{\prime}$.

Mr. Kanai also obtained at Kamisuwa-machi, in the same Ken, an example of Vespertilio murinus superans Thos., a Bat new to the fauna of Japan.

* Ann. Mag. N. H. (6) xix. p. 161 (1897). 


\section{Lutreola sibirica Pall.}

o. 1262, 1269, 1276. Sasuna, N. Island.

These specimens agree absolutely in size, colour, and length of tail' with Vladivostok and other mainland examples of the group, and equally differ from the Japanese Putorius itatsi.

On the other hand, the Quelpart Minks, which I had supposed to be summer representatives of sibiricus, prove on a closer examination to be more allied to itatsi, though separable from it*. In both islands, therefore, the members of the present genus exactly contradict the conclusions as to the faunistic relations of Quelpart and Tsu-shima with Korea and Japan, indicated by Urotrichus and the Mice.

"The most common of the Carnivora of the Islands ; not living near houses, but in the wooded hills. Sometimes eaten by the fishermen. Called 'Yoto-shi'=Night-thief."-M.P.A.

\section{Mus norvegicus Erxl.}

§. 1267. ․ 1268. Sasuna, N. Island.

"Common on the sea-shore, where I found it living among the rocks. Fishermen told me that it swims in the sea." -M. P.A.

\section{Apodemus speciosus Temm.}

o. 1252, 1270. q. 1250, 1251, 1253, 1264, 1271, 1280. Sasuna, N. Island. 100'.

ㅎ. $1202,1207,1210,1227,1236,1241$. ․ $1201,1208,1220$ 1239. Izuhara, S. Island. $300^{\prime}$.

These specimens are absolutely speciosus and not peninsulce, thus agreeing with the other Rodents in their Japanese rather than Korean relationship.

\section{* Lutreola quelpartis, sp. n.}

Size as in $P$. itatsi, the Japanese Mink, markedly smaller than in the Korean $P$. sibiricus. General colour, in summer pelage, dark tawny or russet-brown, quite as in P. itatsi. Face dark "seal-brown"; under surface, tail, and sides of neck russet; lips and chin white; hands and feet russet, passing terminally into drab.

Skull with a very high and vaulted brain-case, much more so than that of either $P$. sibiricus or itatsi. Upper molar with its inner lobe narrow, the antero-posterior diameter of this lobe little or not more than that of the outer lobe, and therefore much reduced as compared with either of the allied forms, in which there is a broadly expanded inner lobe.

Dimensions of a pair, measured in flesh :-

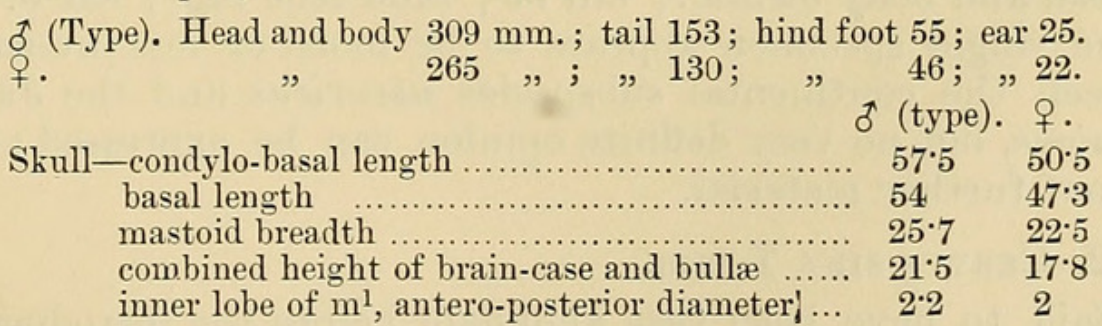

Hab. Island of Quelpart, S. of Korea.

Type. Adult male. B.M. No. 6.12.6.1. Original number 627. Collected 7th September, 1905, by M. P. Anderson; presented by the Duke of Bedford, K.G. (Four specimens examined.) 
Four fairly large specimens measure :-

o. Head and body $107 \mathrm{~mm}$.; tail 100 ; hind foot $25 \cdot 5$; ear 16 .

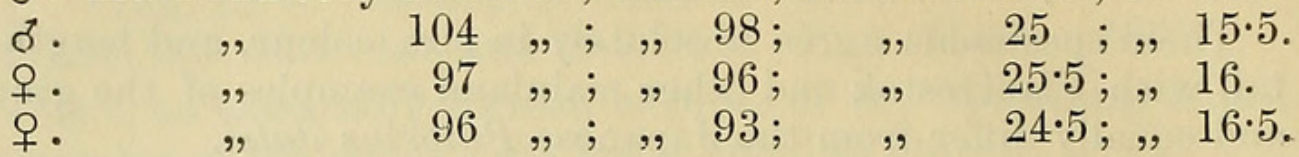

10. Apodemus geisha sagax, subsp. $n$.

ㄱ․ $1245,1246,1249,1254,1255,1256,1257,1258$. 우. 1248 , 1259, 1260, 1265, 1266. Sasuna, N. Island. $100^{\prime}$.

o. 1206, 1211, 1212, 1217, 1222, 1224, 1225, 1228, 1230, $1231,1232,1237,1240$. ㅇ. 1200, 1205, 1209, 1216, 1218, 1219, 1223, 1226, 1229, 1233, 1238, 1239. Izuhara, S. Island. $200^{\prime}-300^{\prime}$.

General characters as in true geisha, but just as the ears average shorter in specimens from Hokkaido*, so here they are uniformly rather longer than in Hondo examples. Of the 25 specimens from Izuhara, in the S. Island of Tsu-shima, no less than 16 are labelled as having ears $15 \mathrm{~mm}$. in length, three have them 14, two $14 \cdot 5$, two $15 \cdot 5$, and two 16 . In true geisha the ears are about $14 \mathrm{~mm}$, and in nokkciidi $13 \mathrm{~mm}$.

The Sasuna specimens are not quite so uniform as those from Izuhara.

Dimensions of four specimens from Izuhara :-

o. Head and body $81 \mathrm{~mm}$.; tail 91 ; hind foot 19.5 ; ear 15 .

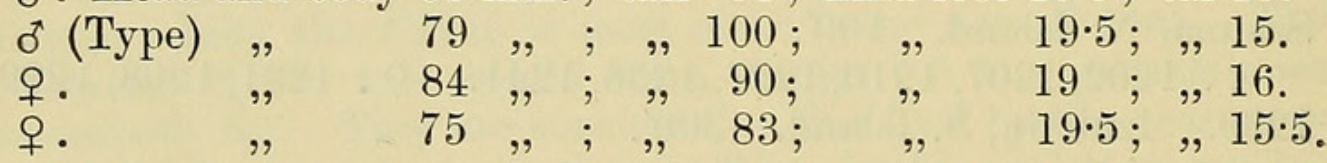

Skull of type-greatest length $24 \mathrm{~mm}$.; basilar length 18; length of upper tooth-series $3 \cdot 5$.

Hah. Tsu-shima-type from Izuhara, South Island.

Type. Adult male. B.M. No. 8.2.26.50. Original number 1228. Collected 10th January, 1907.

"The most common of the Tsu-shima mammals. Found in the forested hills and canyons."-M.P.A. Korea.

Purely a Japanese type, no Mouse at all allied occurring in

11. Apodemus minutus Pall.

o. 1235. Izuhara, S. Island.

Head and body $54 \mathrm{~mm}$.; tail 53 ; hind foot 14.5 ; ear 9 .

The single specimen appears to be more or less intermediate between the continental subspecies ussuricus and the Japanese japonicus, but no very definite opinion can be expressed about it without further material.

\section{[12. Cervus sika Temm.}

"Said to have been very abundant before the introduction of good firearms; now rare and not seen by me or my assistant."M.P.A.] 


\section{$2 \mathrm{BHL}$ Biodiversity Heritage Library}

Thomas, Oldfield. 1908. "The Duke of Bedford's Zoological Exploration in Eastern Asia.-VII. List of Mammals from the Tsu-shima Islands." Proceedings of the Zoological Society of London 1908, 47-54.

https://doi.org/10.1111/j.1096-3642.1908.tb01833.x.

View This Item Online: $\underline{\text { https://www.biodiversitylibrary.org/item/97671 }}$

DOI: https://doi.org/10.1111/j.1096-3642.1908.tb01833.x

Permalink: https://www.biodiversitylibrary.org/partpdf/72429

\section{Holding Institution}

Smithsonian Libraries

\section{Sponsored by}

Biodiversity Heritage Library

\section{Copyright \& Reuse}

Copyright Status: Public domain. The BHL considers that this work is no longer under copyright protection.

This document was created from content at the Biodiversity Heritage Library, the world's largest open access digital library for biodiversity literature and archives. Visit BHL at https://www.biodiversitylibrary.org. 